\title{
Down in Davenport: A Regional Perspective on Antebellum Town Economic Development
}

\section{TIMOTHY R. MAHONEY}

IN THE 1850s the river towns of eastern Iowa emerged as dynamic places that provided goods and services for the wave of settlers then streaming into Iowa and the West. Believing that each urban place could develop into both a replica of local town economies and societies elsewhere and a microcosm of the larger economy and society as a whole, the founders of these towns had initially sought to make them the centers of autonomous local economies. However, the development of a regional economy, based on the emergence of a hierarchical urban system, altered the basis of local urban development. Rather than relying on providing goods and services to their local hinterlands, towns increasingly felt pressure to broaden their economic functions within the new urban system in order to continue developing. In response to heightened competition from nearby towns, local elites were compelled to formulate more assertive and ambitious economic strategies. The economic elite of these towns came to believe that the town that could specialize and generate external and transport economies would broaden the reach of its trade, draw other towns into dependent economic relationships with it, and emerge as a significant regional entrepôt. In time, by attracting railroads, further expanding trade, and establishing new financial contacts with larger cities back east, so it was believed, centrality elsewhere would migrate farther west and propel the suc-

THE ANNALS OF IOWA 50 (Summer 1990). (CThe State Historical Society of Iowa, 1990. 
cessful entrepôt city to metropolitan status in the midwestern urban system.

Then, between 1857 and 1865, something unexpected happened to the ambitions of one river town after another. Each town actively sought to attract railroads as the catalysts of further development and regional control, but their arrival shifted mercantile connections from St. Louis to Chicago, and brought agents, branch offices, traveling salesmen, and catalogs from the metropolis. Gradually, local manufacturers and merchants were forced out of business, transshipping activity moved elsewhere, and the local dynamics of economic development atrophied. One by one local economic actions were drawn into the regional economic dynamics centered at the metropolis. Forced either to coordinate local economic activity with or differentiate it from metropolitan activity, the course of local development fragmented, and change came more slowly and discontinuously, usually introduced from the outside. As this happened, those who stayed abandoned their earlier ambitions and goals, and increasingly relied on compromise, adjustment, and rationalization. Rather than acting on their own initiative, locals tended to respond passively to outside decisions. ${ }^{1}$

This reorientation to the realities of the new regional system pushed the history of many such towns to the side. Life in these towns seemed to fall behind the pace of regional and national development, and the local economy seemed no longer able to keep up with the competition among larger cities, which increasingly took place at a higher level of functional specialization and development across the regional system. As a result, such towns retreated to providing goods and services to a small local area, an economic eddy, a backwater in the regional system.

Given the metropolitan ambitions of the first generation, anything short of becoming a metropolis was perceived by residents and observers alike as failure. Such places were increasingly considered stagnant, redundant, and simple urban places of little interest. Ignored or treated as a dependent by the

1. Robert H. Wiebe, The Opening of American Society: From the Adoption of the Constitution to the Eve of Disunion (New York, 1984), 287-90; Jonathan Raban, Old Glory: An American Voyage (New York, 1981), 193. 
metropolis, some localities responded to relative decline within the system by ignoring its implications and asserting that local history still followed the same local linear process of development as they thought it always had. They argued that each community should be judged on its own terms. What would be seen from a regional perspective as decline or just keeping up was interpreted locally as progress. No matter that paved streets, sewer systems, streetcars, or telephones arrived years after their appearance in the metropolis, each still marked a milestone in the advance of progress in a town. Local life, viewed out of all context, became parochialized and isolated from the broader history of the regional system of which it was a part.

Ironically, the tendency among historians to analyze towns and communities as case studies of sets of other such towns and communities reinforced the tendency to view town histories as individualized and isolated from those of other urban units. Either way, the real story of these towns, their continual struggle to respond to and interact with the overwhelming power of the metropolis in the regional system has been understated, if not ignored, by residents, local historians, and, more recently, professional historians.

Yet this continual struggle of small and middle-sized towns and cities in the hinterland to find a useful role within the metropolitan-dominated regional system is the distinguishing historical experience of these places. In the nineteenth century more than half of the towns and cities in modernizing America experienced urbanization from this hinterland perspective, and it remains the primary experience of most towns and cities today. Connecting the history of such towns and cities to the larger process of regional metropolitan development forces a reconsideration of these places not as failed towns, but rather as secondary places within regional systems. In the words of the urban historian Eric Monkkonen, they "enhanced agriculture, fed the larger cities, [and] helped build a rich network of transportation and manufacturing throughout the country" by serving place-specific functions within the larger process of regional urbanization and development. ${ }^{2}$

2. Eric Monkkonen, America Becomes Urban: The Development of U.S. Cities and Towns, 1780-1980 (Berkeley, CA, 1988), 24-26, 123. 
From the beginning, the history of each town was shaped by the ways townspeople responded to the shifting realities of the regional economic system. Because this development dovetailed with the rapid growth of one or two urban centers, responses were necessarily directed at competing or interacting with larger cities. Each town's response shaped the continuing character of its economic and social development and structure. Their responses formed the tenuous thread connecting successive generations and giving each town's history a plot and some direction, albeit not always positive. ${ }^{3}$

The plot inevitably involved a complex interaction between perceptions, assumptions, expectations, actions, and systemic reality. That interaction, as it played out in the relatively well-documented early history of Davenport, Iowa, is the focus of this article. Told from this perspective, the story adds new meaning and broader comparative significance to the local historical perspective. By showing how Davenport's merchants and entrepreneurs developed economic strategies in a regional context and thus shaped the distinctive historical experience of the town, one can begin to understand the relationship between economic and social actions and strategies and how their interaction contributed to the evolution of a distinctive social milieu in Davenport.

LOCATION, in Davenport's case, had much to do with its destiny. The first traders and trappers who moved north on the river quickly recognized the potential significance of the area when they encountered, in rapid succession, a great bend eastward in the river channel, the mouth of the Rock River on the east bank of the river, Rock Island sitting in the middle of the river a bit farther upriver, and the lower end of the upper rapids of the Mississippi just above the island. The rapids seemed a natural break in river travel, while the island or the elevated banks on the west seemed a secure place to establish a post with contact with the Rock and upper Mississippi river valleys. The presence of a considerable settlement of Sauk Indians just up

3. Ron Powers, White Town Drowsing (Boston, 1986), 20-34. 
the Rock River further attested to the strategic importance of the site.

Between 1808 and 1816 the American government established four forts on the upper Mississippi River: Fort Madison, established in 1808 but evacuated and burned in 1813; Fort Edwards at the lower rapids near the mouth of the Des Moines River and the later site of Warsaw, Illinois, in 1810; Fort Crawford, at the site of Prairie du Chien at the mouth of the Wisconsin River in 1815; and Fort Armstrong on Rock Island in 1816. A few years later Fort Snelling was built near the site of St. Paul. Although it would be an exaggeration to describe the placement of these forts as a system, it is clear that military and civilian personnel on the upper Mississippi did occasionally move from fort to fort, and that there was a regular pattern of supply from St. Louis to the north, touching at each of the forts. Each in itself, however, was only an outpost, supplied from the outside with food, stores, and goods to trade with the surrounding Indian population. The forts were not necessarily "spearheads of urbanization," for only Fort Madison and Fort Crawford developed into actual town sites. Those involved in supplying or occupying the upper Mississippi River forts did, however, naturally acquire a sense of geography and knowledge of the territory. That knowledge may have enabled them to make informed locational choices when the wave of American settlement hit, land prices became tied into a land market, and investors, each hoping to make a profit, scattered town sites across the upper river valley. ${ }^{4}$

George Davenport, Sr., for example, successfully maneuvered within the outpost and fort system and then used the knowledge thus gained to his advantage when settlement and urban development began to interact in the 1830 s. As early as

4. The History of Lee County, Iowa (Chicago, 1879), 327-31, 590-91; Nelson C. Roberts and S. W. Moorhead, eds., Story of Lee County, Iowa, 2 vols. (Chicago, 1914), 1:113-21. Franc B. Wilkie, Davenport, Past and Present (Davenport, 1858), 150-51; Bruce E. Mahan, Old Fort Crawford and the Frontier (Iowa City, 1926), 34-48; History of Dubuque County, Iowa (Chicago, 1880), 152-56; David Wishart, The Fur Trade of the American West, 1807-1840: A Geographical Synthesis (Lincoln, NE, 1979); Richard C. Wade, The Urban Frontier: Pioneer Life in Early Pittsburgh, Cincinnati, Lexington, Louisville, and St. Louis (Chicago, 1959), 1. 
1814 Davenport, acting as an agent for the American Fur Company, was supplying upriver forts from St. Louis. In late 1815 he was present at the construction of Fort Armstrong. The next year he opened a trading post at the fort. By 1818, however, Davenport had apparently moved out of the fort and established his own independent trading post elsewhere on the island. Meanwhile, he had established a series of temporary posts across the central valley to trade with the Sauk and Mesquakie Indians (known to the federal government as the combined Sac and Fox tribes) and, further north, the Sioux. ${ }^{5}$

Davenport also became the first white person since the death of Julien Dubuque in 1810 to gain the trust of the Mesquakie Indians who extracted lead from the mines around Dubuque and Galena. Davenport's efforts to become the broker for the trade between the Indians and St. Louis merchants were hindered by the actions of competitors, in particular the futile efforts of Col. John Smith of St. Louis to forcibly wrest control of the mines from the Indians. Nevertheless, by 1818 Davenport had begun to ship lead south to St. Louis. ${ }^{6}$

In 1819 a number of settlers arrived in the lead region. Several more groups followed in 1820, and in 1821, amid a national recession, a wave of settlers ventured north along the river and established uncertain claims to the mines around Galena, Illinois. That same year Davenport himself sent an associate, Amos Farrar, to set up a permanent trading post at Galena, thus establishing the town as the entrepôt of the lead region and a significant regional outpost north of St. Louis. ${ }^{7}$

In 1821 the regional cluster of settlements and economic development concentrated around St. Louis was just then moving north past the newly established town of Quincy into Adams County and the lower Military Tract. The development

5. Wilkie, Davenport, Past and Present, 150-55.

6. Wilkie, Davenport, Past and Present, 155-57; J. Thomas Scharf, History of St. Louis City and County, 2 vols. (Philadelphia, 1883), 1:187; Jacob Van der Zee, "Early History of Lead Mining in the Iowa Country," Iowa Journal of History and Politics 13 (1915), 3-32, 41.

7. Bernard H. Schockel, "The Settlement and Development of Jo Daviess County, Illinois," in Arthur C. Trowbridge and Eugene W. Shaw, ed., The Geology and Geography of the Galena and Elizabeth Quadrangle (Urbana, IL, 1916), 184; Wilkie, Davenport, Past and Present, 156. 
of a cluster of settlements in the lead region and the establishment of Galena as the endpoint of an outpost economy north of St. Louis established a geographical pattern of economic development in the central part of the upper Mississippi River valley. These two areas of rapid development at either end of the regional system were connected, after 1823 , by a developing transport system. Between them, the valley between Quincy and Galena took on the concerns of an in-between place. ${ }^{8}$

After Fort Armstrong lost its outpost or break-of-bulk economic function to Galena about 1825 , newly arriving entrepreneurs and traders in the central part of the valley had to settle for developing some intermediary role in the entrenched regional outpost system. Those interested in establishing towns or cities thought in terms of supplying steamboats with food and fuel, travelers with a place to rest, and merchants and ships with a place to store or transfer goods or break large shipments into smaller, more local ones. In each case, the establishment and future success of a town or city was justified, encouraged, advertised, and predicted on the strength of its proximity to either of the rapids or its convenient location halfway between St. Louis and the lead region. ${ }^{9}$

When the wave of settlement finally pushed north into the central valley, the stretch of the river between the rapids became a hotly contested area for town development. As early as 1819 guidebooks pointed to the area's promise. By the early thirties, locational advantages were amplified by the growing awareness that the richness of the soil along and behind the river banks increased as one progressed north along the river. ${ }^{10}$ Hence, earlier perceptions intersected with the line of first set-

8. Theodore L. Carlson, The Illinois Military Tract: A Study in Land Occupation, Utilization, and Tenure (Urbana, IL, 1951), 2-3; William V. Pooley, "The Settlement of Illinois from 1830 to $1850, "$ Bulletin of the University of Wisconsin, History ser. 1 (May 1908), 400.

9. Ronald Rayman, "The Black Hawk Purchase: Stimulus to Settlement of lowa, 1832-1851," Western Illinois Regional Studies 3 (Fall 1980), 141-53.

10. Edmund Dana, Geographical Sketches on the Western Country; Designed for Emigrants and Settlers (Cincinnati, 1819), 134-37, 146-47, 297-98; Edmund Dana, A Description of the Bounty Lands in the State of Illinois; Also the Principal Roads and Routes, by Land and Water through the Territory of the United States (Cincinnati, 1819), 5-9. 
tlement and a speculative regional economy to touch off urban land speculation between the rapids, especially within twenty miles of the vacant site of Fort Armstrong.

In the apparently chaotic, random progression of town development in this area, those who had been involved in the earlier trading and fort system had a distinct advantage. They initially chose most of the best sites, leaving less advantageous sites for newcomers and outsiders. George Davenport's post on Rock Island was, not surprisingly, a springboard from which several early town founders started. Davenport's early associates included Russell Farnham, the founder of Rock Island in 1826; John Vanatta, founder of Keithsburg, Illinois, in 1827 and Muscatine in 1835; Antoine LeClaire, an interpreter at the fort and one of Davenport's founders; Benjamin Clark, the founder of Buffalo in 1833; and James Bourne, the first settler near the site of Clinton in 1836. Davenport's son, George L., crossed over to Iowa in 1832 to claim a townsite near Davenport, as did two other relatives, who laid out Rockingham in $1836 .{ }^{11}$ Meanwhile, newcomers to the region, responding to the initial interest by locals and to guidebook advice, filled the areas in between these fledgling towns with at least twenty more townsites before 1860 .

The intense interest of town developers in the area between the rapids is evident from the numbers of towns founded or platted out. Most developers apparently believed that a significant town or city would develop somewhere about halfway between Galena and St. Louis. At a general level, therefore, action seems initially to have reflected assumptions. The situation soon became more complex, however. The changing dynamics of the regional urban system altered local experience. Assumptions and other ideas about what was possible or desirable had to be adjusted to fit that experience, and actions, in turn, took on new forms.

11. Pooley, "Settlement of Illinois," 423; History of Mercer County, Illinois (Chicago, 1882), 46-47, 118; A. T. Andreas, Illustrated Historical Atlas of the State of Iowa, 1875 (Chicago, 1875), 426-27, 449, 484; A History of Scott County, Iowa (Chicago, 1882), 122; Sylvester W. McMaster, Sixty Years on the Upper Mississippi: My Life and Experiences (Rock Island, 1890), 90; Willard Barrows, "History of Scott County, Iowa," Annals of Iowa 1 (1863; reprint, Iowa City, 1964), 42, 97, 21. 
Initially, most of the towns between the rapids seem to have been competing for the secondary role of entrepôt for eastern lowa, nothing more. At the time, the regional urban system was clearly organized as an outpost economy. All new towns somehow had to find a useful niche within that prearranged structure. As the wave of regional settlement swept into eastern Iowa after 1850, this arrangement faced increasing pressure and began to show signs of being stretched to the limit. Consequently, the larger towns along the river temporarily abandoned the passive strategies of economic integration within a system for more independent strategies such as direct competition, import substitution, specialization, or entrepôt bypassing.

In the 1850 s Davenport in particular aimed its sights higher, seeking more than secondary status, and even, perhaps, a role as entrepôt for the entire region. All the while, however, the forces at work were really reinforcing, not undermining, the power of the existing regional entrepôts. New assumptions, buoyed by economic expansion and distorted by speculation, elicited new actions, blinding locals to the reality of new regional metropolitan dynamics of urbanization, dynamics that would, in time, compel secondary towns to retreat to more passive strategies of survival through integration in a regional urban system. ${ }^{12}$

THE SHIFTING CHARACTER of the economic strategies of Davenport's merchants and entrepreneurs was best characterized by the career of Antoine LeClaire. LeClaire was the halfbreed son of a French fur trapper and a Potawatomie woman, and, since 1822, the husband of the granddaughter of a Potawatomie chief. His power in the region was rooted in the treaty of 1832 ending the Black Hawk War. By the terms of the treaty the Sauk and Mesquakie Indians ceded the land for fifty miles west of the Mississippi River. In return for his services as

12. Timothy R. Mahoney, River Towns in the Great West: The Structure of Provincial Urbanization in the American Midwest, 1820-1870 (Cambridge and New York, 1990), 105, fig. 4.1; John D. Haeger, "The Abandoned Townsite on the Midwestern Frontier: A Case Study of Rockwell, Illinois," Journal of the Early Republic 3 (1983), 165-83. 
an interpreter during the war and earlier, LeClaire received three large land grants on the banks of the river in the vicinity of Fort Armstrong. The first grant, at the future site of Moline, Illinois, had been acquired in 1829 and then disputed by the Indians, leading to the Black Hawk War; the other two were across the river, one near the future site of LeClaire and the other just east of the future site of Davenport. Aware of the potential value of the third grant, LeClaire decided to focus his energies on it. In 1832 he and his wife crossed the river and established residence there. In the ensuing year, using his land as collateral, he gradually bought out early claimants who held large blocks of land to the west of his own. In late. 1835 he sold a large tract of land to the west of his original grant to the proprietors of the newly founded town to be called Davenport. Later he joined them to establish a broad plat for the new town. ${ }^{13}$

An unenthusiastic response to the public sale of town lots in 1835 and 1836 convinced LeClaire, Davenport, and other newcomers that more needed to be done to draw attention to the new town. After all, in mid-1836, Davenport was but one of many towns in the vicinity vying for the role of local depot and thus the primary urban center in the middle of the valley. First, the founders sought to acquire political centrality in the county, that is, to secure the county seat.

The major initial contender was Buffalo, a town established downriver a few years earlier. Given the contemporary expectation that county seats should lie near the center of a county, Buffalo's location closer to the center of Scott County weighed heavily in its favor. To counteract this advantage, LeClaire, unable to change the location of his town and unwilling to start another elsewhere (due to Davenport's other locational advantages), sought to relocate Davenport to the center of the county by having the county line moved upriver. As it happened, LeClaire's interests corresponded with those of Dr. John Reynolds, a legislator from Muscatine County. As

13. J. W. Spencer, "Reminiscences of Pioneer Life in the Mississippi Valley," in Milo Milton Quaife, ed., The Early Day of Rock Island and Davenport: The Narratives of J. W. Spencer and J. M. D. Burrows (Chicago, 1942), 43; Barrows, "History of Scott County," 40-44,58-59; Davenport Democrat, 15 February 1873. 
founder of Geneva, a town a few miles upriver from Bloomington (later Muscatine), Reynolds faced a similar problem. LeClaire and Reynolds thus pooled their resources and power to convince legislators to move the Scott-Muscatine county line upriver, thereby placing both Davenport and Geneva nearer the center of their respective counties. ${ }^{14}$

As a result of these maneuvers, the competition then focused on Davenport's nearby, larger (as late as 1838) neighbor, Rockingham. A series of elections for the county seat was marred by repeated fraud by both sides and the inevitable demands for recounts. By the time the territorial legislature intervened in 1838, economic geography and LeClaire's establishment of a ferry line across the river in 1836 had decided the outcome. John Burrows later remarked that while charge and countercharge flew back and forth for two years, Davenport simply passed Rockingham by in both "population and capital," causing even some Rockingham residents to "desert to the enemy." The discovery that Rockingham's wharf, unlike Davenport's, lay below the spring flood level also worked to its considerable disadvantage. Moreover, Davenport's expanding capital enabled its citizens to offer to build a substantial courthouse "equal to the court-house across the river, at Stephenson, Illinois. ${ }^{.15}$

Thus Davenport carried the day. Soon it emerged as the depot along the Great Bend of the Mississippi and began to connect itself to regional channels of trade. In that regional context it would eventually find new competitors for the status of subregional entrepôt. That competition would require Davenport's elite to adopt new, broader strategies of action to achieve their goals.

In the meantime, LeClaire continued to consolidate his control of the town by manipulating the land market, and further encouraging local economic development. Land sales had

14. Andreas, Historical Atlas, 426-27.

15. Ibid.; J. W. Parker to Thomas McKnight, 14 March 1838, Thomas McKnight Papers, State Historical Society of Iowa, Iowa City, Iowa; J. M. D. Burrows, "Fifty Years in Iowa: Being the Personal Reminiscences of J. M. D. Burrows," in Quaife, Early Day, 121-22; Wilkie, Davenport, Past and Present, 221-23, 233. 
remained sluggish on the Davenport plat. Because of some uncertainty about the legitimacy of the proprietors' deed, they were unable to transfer land fee simple to prospective purchasers. But LeClaire, who had full title to his land by treaty rights, could circumvent the confusion of territorial laws and transfer immediate title to newcomers. So in 1839 he decided to plat out the First Addition as an independent proprietor. Within a few weeks, land sales began to concentrate in the area along Main and Brady streets behind LeClaire's wharf, which he had built the same year to draw steamboat traffic to the site. Every two years for the next fifteen years LeClaire opened new additions, moving up the bluffs from the original plat. Antoine LeClaire thus became Davenport's dominant proprietor. ${ }^{16}$

LeClaire continued to add to his influence in the community. By 1840 the LeClaire House, the hotel he had built in 1838 , had become a popular resort for southerners. In 1841 he made extensive land grants to schools and churches to encourage their construction. He also seems to have built housing for prospective settlers, either renting or selling the dwellings depending on the circumstances. According to one biographer, he "improved the city by a liberal expenditure of a large income, in erecting churches and other public buildings." Improvements scattered about the city memorialized his generosity. ${ }^{17}$

Although there is little concrete evidence concerning LeClaire's involvement in real estate and building, it did draw comment from contemporary observers. One traveler from Dubuque noted that Davenport in the mid-fifties seemed much more built up than Dubuque, even though both were about the same size. "This is owing to its being owned (or at least threefourths of it) by a Frenchman named LeClaire who is determined to have a town there. It requires, however, something besides buildings to make a place important and that something is not in Mr. LeClaire's power to bestow." ${ }^{18}$

16. Barrows, "History of Scott County," 58-59, 64, 68, 74-76.

17. History of Scott County, Iowa, 609; [H. A. Porter], Rock Island and Its Surroundings in 1853 (Rock Island, 1854), 27.

18. Diary of William J. Barney, Dubuque, Iowa, State Historical Society of Iowa, Iowa City. 
LECLAIRE, of course, was aware that a town was more than a plat, a wharf, buildings, churches, and public institutions. The town needed a market orientation capable of expanding from local to subregional exchange and specialization. The first merchants who arrived in town in the late thirties set out to accomplish that goal.

By 1835 Davenport had become a stop on the steamboat route between St. Louis and Galena. By that time eleven boats regularly negotiated the upper river. ${ }^{19}$ At first, the steamboats merely dropped off immigrants and goods from St. Louis and continued on to St. Louis or Galena without taking on any freight. As Scott County's population continued to grow, however, early Davenport settlers, whether merchants or not, began to feel the inevitable demands from newcomers to provide specialized market and craft services.

As early as 1838 several of the one hundred or so townspeople had begun to specialize as merchants or peddlers. David A. Burrows began peddling fruits and vegetables in 1839 . The next year his brother John "laid in a supply of goods" from his cousin in Cincinnati and became the town's first permanent merchant. By the year's end local farmers had exhausted his supply of groceries. The next year he added dry goods to his stock and began to extend credit to local farmers. In some cases he even filled in for absent bankers, holding money deposits for clients until they wished to apply them to the purchase of goods, or sometimes transmitting them to St. Louis merchants. ${ }^{20}$

By 1839 Burrows's business had begun, by his account, to attract trade from Clinton and Jackson counties, as well as throughout Scott County. In 1840, to the surprise of the four other merchants in town, Burrows also began to buy produce, grain, and livestock from the nearby farming population, which had already begun to produce surpluses. In the next two years he commenced selling produce upriver at Fort Crawford and Fort Snelling and at Potosi, Wisconsin, hence tying into the arrangement Davenport had been a part of a decade earlier. In 1841 he acquired contracts for the fort trade. This required him to purchase larger amounts of grain, livestock, and produce

19. Scharf, History of St. Louis, 2:1102.

20. Burrows, "Fifty Years in Iowa," in Quaife, Early Day, 142-44. 
from area farmers. By the end of the year, Burrows's trade, and thus Davenport's influence, extended to Clinton, Jackson, Cedar, and Linn counties, and into the trading territory of Rock Island across the river. ${ }^{21}$

By 1843, having exhausted demand in the north, Burrows turned his sights to regional markets in St. Louis and New Orleans. Twice he attempted to use flatboats to send produce downriver to New Orleans. By 1845, however, Burrows found St. Louis the preferable market. With credit from St. Louis entrepreneurs, Burrows and others began to extend their credit arrangements with farmers across a broader hinterland, and thus established Davenport's position as a central place between St. Louis wholesalers and the newly settled farms of eastern Iowa. ${ }^{22}$

Davenport consolidated its regionally oriented function in the middle of the valley in the middle 1840s, when wheat shortages in Europe led to high prices and a wheat boom for American farmers. By the middle of the decade, with more than four hundred steamboats arriving every year, local merchants sent an average of about thirty thousand bushels of wheat into the regional market. Although this was less than half the amount exported from Quincy and Alton downriver, it did approximate the levels at Burlington and Dubuque, and it outstripped the volume of trade at Muscatine, Rock Island, and Clinton, Davenport's nearest competitors. Apparently a kind of subregional shakeout in the market had begun to consolidate the wheat trade in a few major centers upriver. ${ }^{23}$

Davenport's competitive advantage was based on its location just below the upper rapids on the Great Bend of the river and far enough north to avoid Quincy's trading power. Merchants in towns above the rapids were forced to pay lower prices than those in towns below the rapids, thus giving Davenport a competitive draw in markets as far north as the back-

21. Ibid., 149-54, 163-69.

22. Ibid., 182-85, 187-88, 192-95.

23. Davenport Gazette, 5 January 1843, 10 June 1847, 6 December 1849; Harry E. Downer, History of Davenport and Scott County, Iowa, 2 vols. (Chicago, 1910), 1:193; Barrows, "History of Scott County," 114; Mahoney, River Towns in the Great West, 189-91. 
country of Dubuque. In 1848 a Dubuque editor complained that Davenport and Muscatine merchants were drawing off a "large portion" of our trade, "just because proprietors of these establishments were paid better prices for their grain than could be received here." ${ }^{24}$ Towns to the south of Davenport were adversely affected by the similar economic and geographic advantages of Keokuk and Quincy. Those towns were powerless to prevent Keokuk from drawing off as much as 25 percent of their potential local trade. Davenport was far enough north of Quincy, by contrast, that Quincy merchants were unable to draw off much of its trade. Thus Davenport was able to increase its draw from the north while maintaining the boundaries of its previous hinterlands to the south. ${ }^{25}$ In each case, Davenport's expansion was aided by a surge in the market price of wheat. At the same time, the relatively stable cost of transportation allowed farmers to carry wheat greater distances than they could have before the price rise.

Import substitution further enhanced Davenport's economic position in the regional system. In 1848 Ambrose Fulton, John Burrows, and Henry Prettyman, one of Burrows's associates, tapped into Davenport's suddenly rich resource base by simultaneously constructing flour mills in town. By producing flour for local consumption and export, the mills ended the town's dependence on flour milled at St. Louis, Quincy, or Dubuque, the latter two places having acquired mills a few years earlier. Such import substituting reduced the local cost of flour, eliminated payments made abroad for transportation and supplies, created some jobs and local demand for manufacturing supplies, and contributed to the development of local economic centrality, thus enhancing the town's larger economic role in the regional system. ${ }^{26}$

In such an economic and geographic eddy, Davenport was able by about 1850 to broaden its role and carve out a signifi-

24. Dubuque Miner's Express, 19 December 1848.

25. Delegates to the Chicago Harbor and River Convention, The Commerce and Navigation of the Mississippi, and also that appertaining to the city of St. Louis, considered with reference to the improvement, by the general government, of the Mississippi and its principal tributaries (St. Louis, 1847), 18-22; Keokuk Whig and Register, 17 September 1847.

26. Burrows, "Fifty Years in Iowa," in Quaife, Early Day, 208-14. 
cant status as a central place or secondary entrepôt within a rapidly integrating regional economic, urban system. In the next decade Davenport's efforts were reinforced by the convergence of three regional economic and geographic developments across its immediate hinterland. The wheat market soared due to European demand. This occurred just as a wave of immigrants was moving into central lowa, causing a rapid increase in agricultural production. As a result, Davenport became as attractive to migrants as its rivals, Galena and Quincy. Its population increased steadily from about nine hundred in 1845 to three thousand in 1851 and ten thousand in 1856. The counties around it showed a corresponding increase. At the same time, farmers across Davenport's hinterland, responding to local climatic conditions, the cost of transport, and the supply and demand dynamics of the regional market at St. Louis, decided to plant wheat. That development consolidated and drew farther north across the central part of the valley a small "wheat belt" that had developed downriver in the 1840s on the northern fringe of a concentrated area of corn and hog production around St. Louis. In response, Davenport merchants marketed more and more wheat into the regional market at St. Louis. The credit earned by this marketing with St. Louis bankers enabled Davenport merchants to purchase more wholesale supplies for their stores from St. Louis or the East to supply the rising population. The connections with St. Louis and the regional market also enabled them to establish Davenport as a significant merchandising depot. ${ }^{27}$

By the mid-1850s, the convergence of these events transformed Davenport into the boom town of eastern Iowa and the Great West. As that happened, local attitudes concerning the town's role in the regional system and its economic future began to change as well. No longer did local control satisfy the ambitions of many of the towns' most important merchants. Rather, they became convinced that Davenport should play a more central role in the economic development of the valley,

27. Mahoney, River Towns in the Great West, 203-4, 179-82; Downer, History of Davenport and Scott County, 1:174, 190, 194, 198, 208; Directory of the City of Davenport for 1856, '57 (Davenport, 1856), 133. 
perhaps, in time, becoming the entrepôt of the upper Mississippi and trans-Mississippi West.

THE BROAD STRATEGY designed to achieve this end involved efforts on several fronts. All of these efforts undermined local control of economic and social actions and subjected the town to increasing control by outsiders. ${ }^{28}$ Most directly related to changes in regional dynamics was the effort to capitalize on railroad development. Local merchants, responding to growing pressures in the steamboat system, launched a concerted effort to draw the railroad to Davenport. With that accomplished, they went out of their way to support the construction of a bridge over the Mississippi River and to secure a right-of-way through the town. The railroad policy pursued by the town's elite evolved from perceptions about the shifting dynamics of the regional trading system, from possible misperceptions about a subtle short-term shift in the local economy's activity in the grain trade, and, finally, from the unencumbered investment portfolios of the elite, which enabled them to act, economically and politically, to achieve what they wanted.

Throughout the late forties and early fifties settlement continued to shift north and west, filling in eastern lowa and causing significant increases in the farming population. With the grain markets already in place, therefore, pressure gradually increased to handle more and more trade. In the early fifties the beginnings of a sustained price increase in the market, accompanied by stable transport costs, extended the range from which grain could be carried to market, increased intercity competition, and thus, on the basis of previous advantages, enlarged the hinterlands of Quincy and Davenport. In the south, Quincy merchants were able to cut significantly into the trade of Keokuk, Fort Madison, and even Muscatine. Davenport, however, still lay too far north, protected by the rapids and distance from Quincy merchants, so Davenport merchants did not find it necessary to expend energy protecting their trade.

28. See Timothy R. Mahoney, "Down in Davenport: The Social Response of Antebellum Elites to Regional Urbanization," Annals of Iowa 50 (Fall 1990), forthcoming. 
Instead, they aggressively went out and broadened their contacts. By 1856 farmers south and west of Muscatine and east of Rock Island, as well as some behind Clinton, Bellevue, and even Dubuque were bringing grain to Davenport. Davenport merchants were also doing business throughout Henry County, Illinois, and as far west as Fort Des Moines. As a result, while receipts leveled off behind Quincy by 1855 , they continued to soar at Davenport and Dubuque; each town was inundated with nearly a million bushels of wheat in 1857 . That this increase occurred during a period of rising prices which peaked in 1854 only accentuated the economic boom and pressure on Davenport. ${ }^{29}$

Curiously, however, flour and wheat exports from Davenport, Dubuque, and other towns between the rapids to St. Louis or, after 1854, Chicago did not increase. St. Louis felt the impact of this development immediately. Between 1842 and 1854 the upper Mississippi River valley's share of total grain receipts at the St. Louis market dropped from 42 percent to less than 25 percent. This decline might have been due partly to fires that reduced the milling capacity of Keokuk, Quincy, and Hannibal, Missouri, but at Davenport the mills continued to increase flour production. $^{30}$ The rising population of the interior probably demanded most of Davenport's flour production, turning the city into a flour producer and shipper as well as a hinterland grain depot.

This short-term change had a significant effect on local economic perceptions and activity. Having a locational advantage over St. Louis producers in the hinterland flour market, Davenport merchants purchased local wheat and, rather than milling what was needed and shipping the surplus to St. Louis, milled as much as they could and sold it back into the hinterland. Credits that once flowed into St. Louis bank accounts from the proceeds of Davenport's surplus grain sales now stayed at home in local banks. Thus, Davenport merchants no longer felt obliged to use St. Louis credits to purchase goods in the regional entrepot. Instead, they had the freedom to acquire

29. Mahoney, River Towns in the Great West, 161-62, 192-94.

30. Ibid., 192-95; Scharf, History of St. Louis, 1126. 
their goods wherever they wished. ${ }^{31}$ This freedom enhanced their sense of local independence and centrality.

This growing sense of Davenport's centrality within the hinterland may have further fueled the city's already high interest in railroads. Davenport merchants, like those elsewhere above the rapids, had become increasingly frustrated with steamboat transportation. As the volume of trade increased at Davenport and other ports while the number of steamboats operating on the river increased only slightly, traffic problems intensified, transport rates rose, and the burden of the extra cost of the rapids became greater. Upriver merchants and farmers were further discouraged because the St. Louis market tended to be already glutted before the products from the Davenport hinterland could reach the market. The farther north one went along the river, therefore, the greater the frustration with the steamboat system. ${ }^{32}$.

The railroad was also seen as a possible way for Davenport's elite to gain some control over transportation to and from the city. In the steamboat trade they had made no progress in breaking the monopoly held by St. Louis and Galena merchants in owning and running the extensive system of steamboats on the upper river. Ironically, however, this lack of investment in steamboats left Davenport's elite, unlike Galena's, unencumbered by previous commitments, and thus better able to respond quickly to investment ventures.

Given the contemporary condition of the market, Chicago looked very good from eastern Iowa. Because Chicago was closer to the East, its market tended to be higher than St. Louis's. It was also closer to eastern Iowa and thus.offered other trading advantages if transport could be found. Likewise, entrepreneurs in Chicago watched as the wheat belt moved northward behind Davenport and Burlington, eyeing this development as a potential rich harvest for the city's ambitions for grain trading.

Frustration combined, then, with ambition, to propel Davenport's elite headlong into the railroad excitement of the era. Ironically, Davenport's railroad policy emerged from a

31. Mahoney, River Towns in the Great West, 195.

32. Ibid., 159-60. 
growing concern about the need to improve the rapids so as to reduce the "toll" being paid by merchants and farmers alike to the freight company owned by merchants in St. Louis and Galena. At a regional convention held at Davenport in September 1849 to discuss the improvement of the rapids and to formulate a general transportation strategy for Iowa in anticipation of a larger transportation convention the following month at St. Louis, Davenport delegates preferred to discuss the development of a strategy for acquiring railroad connections. ${ }^{33}$

Alfred Sanders, a close associate of Antoine LeClaire, expressed LeClaire's view that more reliance on the river would not enable Davenport to secure a transport connection sufficient to alter their economic position in the current system. "It is undoubtedly true," he remarked, "that the improvement of the rapids would advance the interests of every resident of Iowa, but how little when compared to the advantages they would reap from the intersection of the state by a great national railroad." The delegates apparently agreed, for they resolved that Davenport should raise a large subscription, the funds from which would be used to encourage the selection of Rock Island, Illinois, as the destination of the proposed railroad out of Chicago. LeClaire offered to run the subscription, and, in time, offered twenty-five thousand dollars to secure Davenport's interests. Perhaps suspecting the hidden agenda of the Davenport convention, few members of the state's steamboat interest showed up. A month later at the St. Louis convention, where delegates met to discuss the choice of the route for a national cross-country railroad, the two interests openly clashed when Alfred Sanders publicly criticized a delegate from Keokuk who sought to represent his town's river interests as those of the entire state. ${ }^{34}$ Meanwhile, Keokuk's merchants and entrepreneurs continued to fight for improvement of the rapids, while looking on aghast as the Rock Island Railroad Company was incorporated and began building toward Rock Island in 1852 . In between, the residents of Muscatine recognized the advantages of a railroad, but doubted that a railroad connection to Davenport would help them, so they refused to cooperate.

33. St. Louis Repubilican, 7-14 October 1849.

34. Ibid.; Davenport Gazette, 13 September, 1, 8, November 1849. 
As the railroad approached Rock Island in 1853, Davenport supporters pooled the money necessary to begin construction of a road west from Davenport. Soon thereafter LeClaire offered the Rock Island Railroad Company a right-of-way through town, made his house available as a depot, and encouraged several investors to build hotels nearer to the station to meet the anticipated rush of travelers into Davenport. Not surprisingly, when the first locomotive was shipped across the river and put on tracks going west, it was called the Antoine LeClaire and emblazoned with a shield containing his portrait. ${ }^{35}$

By 1854 the new railroad had reached Rock Island. After two years of construction, it crossed the bridge-the first to span the Mississippi River-into Davenport, establishing the Davenport depot as the railhead on the new western line out of Chicago. Thus the economic orientation of the town shifted dramatically to the East. Within eighteen months, two-thirds of the produce once sent from Davenport to St. Louis was diverted by rail to Chicago. What perhaps surprised Davenporters was that much of this produce was now raw materials just being shipped to Chicago through Davenport, rather than being milled or processed there. Instead of becoming a center of local trade and production, town merchants and entrepreneurs quickly saw the development of a simple transshipping function, with its limited opportunities for agglomeration. Likewise, old mercantile arrangements with St. Louis were thrown over for new ones with Chicago and New York.

At the same time, Davenport was flooded with entrepreneurs, agents, and capitalists from the East and Chicago interested in opening branches of wholesaling houses or in founding processing plants and manufacturing establishments to supply the newly acquired markets. Local craft shops, breweries, flour mills, and foundries succumbed to competition from newcomers or outsiders; even Antoine LeClaire's foundry was among those forced out of business. ${ }^{36}$ Trade may have been up,

35. Rock Island and Its Surroundings, 27; Downer, History of Davenport and Scott County, Iowa, 726-27; Barrows, "History of Scott County," 119-20; Wilkie, Davenport, Past and Present, 114-22; City Journal, City Council Proceedings (Davenport, 1862), 15 September 1858.

36. Manufacturing Census Schedules, Seventh Census of the United States, 
investment was up, the total amount of manufacturing had nearly tripled, but the town's exports remained about the same. The hotel business and packet business to Davenport for travelers did increase, but steamboat arrivals and trade on the wharf declined to less than half of their earlier levels. ${ }^{37}$ The function of the town seemed strangely disoriented, on the verge of being gutted by outside interests. Rather than having its centrality reinforced by the railroad, Davenport was becoming an outpost of the metropolis.

The crash of 1859 in Davenport, which caused the financial failure of several of the most important merchants in town, and even hurt Antoine LeClaire, left the economic leadership of the town in a shambles during a period of significant functional change. While the old economic elite sought to recoup, or simply survive, newcomers took over and established railhead trading arrangements with Chicago. Later, Davenport briefly enjoyed some success in the lumber milling business, the logs brought downriver by rafts from Wisconsin and Minnesota. But Dubuque and Burlington had better rail connections to the West and thus drew off much of the lumber trade. When the railroads moved farther west into Iowa after the Civil War, many of the functions associated with the railhead moved west with them, making Davenport just an important stop along the line. By the late 1860s, therefore, Davenport had retreated into the role of a local specialized manufacturing and trade center. ${ }^{38}$

THE EFFORTS by Davenport's economic elite to expand the town's role in the regional system in the 1840 s and 1850 s ultimately became a lesson in the dynamics of power within such systems. They started from scratch and nursed the town through various frontier stages of economic development to become a central place entrepôt for market farmers across east central Iowa. Then they developed strategies of action based on

1850, Scott County, Iowa; ibid., Eighth Census of the United States, 1860; Rock Island and Its Surroundings, 28-32.

37. Davenport City Directory, 1858.

38. Agnes M. Larson, History of the White Pine Industry in Minnesota (Minneapolis, 1949), 105, 107, 122, 125; Walter A. Blair, A Raft Pilot's Log: A History of the Great Rafting Industry on the Upper Mississippi, 1840-1915 (Cleveland, 1930), 256-65. 
independent, local theories of economic growth and development. For them, establishing connections with St. Louis, encouraging outside investment in local activity, actively seeking to substitute imports, financing railroad construction across the river, and establishing new trading contacts with eastern markets were actions designed to increase Davenport's centrality. Such actions would, they believed, trigger and intensify the local dynamics of economic development, first by creating a threshold of local demand to encourage development of local trade and manufacturing, then, through economies of scale, by creating external economies and clustering advantages that would draw producers and suppliers to town from elsewhere in the region. At each stage of this local development, Davenport would broaden its trade, extend its control, bring more and more producers and customers under its influence, and make more people in its hinterland dependent on its actions.

The vigor and diversity of Davenport's antebellum elite's aggressive strategies, as well as their relative success rate, are impressive. In large part their success was due to their relative unity. The town's location at a prime site for urban development in the midst of a hotly contested area also supported their actions. Antoine Leclaire, the first to arrive and, from the returns on an extraordinary land grant, become wealthy, emerged as the town's leading capitalist. Local plans or efforts did not have to await the interest of outsiders to move forward. Oligarchical economic rule, by intensifying the alignment between personal welfare and town economic development, thus clarified economic decisions and actions, in noticeable contrast to many other hinterland towns across the region.

Ironically, however, the unity of the town's elite may have allowed the assumptions of one man or a small group to go unchecked or unexamined. The elite thus may have committed the town's resources to an overambitious or otherwise errant economic strategy. By putting all their hopes in one effort, the elite tended to invest too heavily in one action and to equate its success with town survival. Inadvertently, they may have imperiled their economic futures by tying personal welfare too closely, or too deeply, to the economic growth of the town. Thus, the town's survival became equated with personal survi- 
val. In towns with more diverse strategies, each citizen's financial welfare was less connected to any one course of development. The Davenport elite's strategic unity and clarity created the impression that their investments were sure things. That illusion accelerated local over-speculation during the good times and extended the limits to which locals would go to stave off the inevitable consequences of a failed investment when things went bad. An unwise single investment thus acquired the leverage to generate personal failure and ruin.

The quest for success under localist assumptions reinforced personal involvement with the town economy, and, in Davenport's case, sharpened the shock of the inevitable confrontation with the forces of the system and deepened the pain of the economic adjustment. It also assured that few of the elite involved in this first strategy would survive to reorient town economic policy to the new realities of the system. Restraint, balance, or diversity on the part of the elite in the 1850s might have better served the future of the town, and allowed its inhabitants to better mediate between local and personal interests and the forces of regional development. Their inability to do this, however, lies deeply imbedded in their particular circumstances, their assumptions, and in the distinctive character of Davenport's society.

Towns and smaller cities and even the metropolises of the Midwest today are still locked in a similar struggle to survive. The struggle requires a delicate balancing act. On the one hand, these places perceive a need to interact, be connected with, join, or respond to the larger national and world system in order to maintain some growth and development. On the other hand, they do not want to allow such connections to coopt local activity, sap the dynamics of the local economy, and undercut any local sense of community and shared social experience. Historically, this struggle has reduced many towns to colonies of franchises, "imported piecemeal, but no less systematically from distant marketing empires. ${ }^{39}$ Yet this very struggle lies at the center of much local history, a history that cannot be told apart from its context of regional change.

39. Monkkonen, America Becomes Urban, 127; Powers, White Town Drowsing, 39. 
Copyright of Annals of Iowa is the property of State of Iowa, by \& through the State Historical Society of Iowa and its content may not be copied or emailed to multiple sites or posted to a listserv without the copyright holder's express written permission. However, users may print, download, or email articles for individual use. 